\title{
KNOWLEDGE, AWARENESS, AND PERCEPTION TOWARDS PROSTHODONTIC TREATMENT AND SERVICES AMONG THE NATIVES OF DURG, CHHATTISGARH
}

\author{
Vivek Lath', Priyabrata Jena ${ }^{2}$, Nitin A. Vaidya ${ }^{3}$, Vidya N. Vaidya 4 , Saumya Sharma 5 , Gulab Chand Baid 6 , Sopan Singh ${ }^{7}$, Neeraj Gupta ${ }^{8}$ \\ ${ }^{1}$ Senior Lecturer, Department of Prosthodontics, Maitri College of Dentistry and Research Centre, Anjora. \\ 2 Postgraduate Student, Department of Prosthodontics, Maitri College of Dentistry and Research Centre, Anjora. \\ ${ }^{3}$ Professor and HOD, Department of Prosthodontics, Maitri College of Dentistry and Research Centre, Anjora. \\ 4 Professor, Department of Prosthodontics, Maitri College of Dentistry and Research Centre, Anjora. \\ 5 Professor, Department of Prosthodontics, Maitri College of Dentistry and Research Centre, Anjora. \\ ${ }^{6}$ Reader, Department of Prosthodontics, Maitri College of Dentistry and Research Centre, Anjora. \\ 7 Senior Lecturer, Government Dental College, Raipur. \\ ${ }^{8}$ Senior Lecturer, Department of Prosthodontics, Maitri College of Dentistry and Research Centre, Anjora.
}

\section{ABSTRACT}

\section{BACKGROUND}

This study evaluates the knowledge, awareness \& perception of patients in the Department of Prosthodontics of Maitri College of Dentistry \& Research Centre of Durg district in Chhattisgarh towards prosthodontic rehabilitation and the factors that prevent them from the treatment. Knowledge and perceived needs of subjects regarding Prosthodontics play an important role in their acceptance to prosthetic rehabilitation.

\section{MATERIALS AND METHODS}

A self-designed questionnaire containing nineteen questions was designed and reasons for choosing or refusing treatments were measured using Likert scale. A survey of 300 randomly selected subjects was conducted among the patients and relatives reported to the Maitri College of Dentistry \& Research Centre.

\section{RESULTS}

Collected data were statistically analysed using SPSS 16.0 for descriptive statistics along with T-test \& Chi-squared test at a significance level of $\mathrm{p}<0.05$.

\section{CONCLUSION}

The present results may serve as a baseline for the future evaluation of attitudes towards replacement of teeth. The findings indicate that awareness needs to be created regarding the other functions of teeth like aesthetics and phonetics.

\section{KEYWORDS}

Knowledge, Perception, Awareness, Prosthodontic Treatment, Survey, Prosthetic Replacements.

HOW TO CITE THIS ARTICLE: Lath V, Jena P, Vaidya NA, et al. Knowledge, awareness, and perception towards prosthodontic treatment and services among the natives of Durg, Chhattisgarh. J. Evolution Med. Dent. Sci. 2017;6(29):2377-2382, D0I: $10.14260 /$ Jemds/2017/512

\section{BACKGROUND}

Today, a modern view of dentistry is one that recognises the emotions or psychological essence of the patient in relationship to the dental situation, dental health care, and, especially, aesthetics. ${ }^{1}$

Teeth play an important role in the maintenance of a positive self-image. ${ }^{2}$ The loss of teeth results in significant disabilities, which can profoundly disrupt social activities. Tooth loss is very traumatic and upsetting and is regarded as a serious life event that requires significant social and psychological readjustment.3,4 In its broadest sense, Prosthodontics is concerned with the replacement of partial or complete loss of teeth and oral function due to tooth or tissue damage (Carlsson GE and Omar R, 2006). With the

Financial or Other, Competing Interest: None.

Submission 02-03-2017, Peer Review 27-03-2017,

Acceptance 03-04-2017, Published 10-04-2017.

Corresponding Author:

Dr. Vivek Lath,

F/301, Ashok Heights, Mowa,

Vidhan Sabha Road,

Raipur.

E-mail: drviveklath@gmail.com

DOI: $10.14260 /$ jemds $/ 2017 / 512$

(c) $(7)$ rapid improvement in oral health and the reduction of edentulism in many countries, increasing numbers of people are retaining more teeth later in life (Carlsson GE and Omar $R, 2006)$. Knowledge of subjects regarding prosthodontic treatment may play a role in their acceptance of the prostheses (Shigli et al., 2007). The aim of this paper is to evaluate the level of knowledge, perception, awareness, attitude, and behaviour of patients in the Department of Prosthodontics of Maitri College of Dentistry \& Research Centre, Durg, Chhattisgarh aged between 21-91 years towards the options available for replacing missing teeth and the factors preventing them from taking treatment.

\section{MATERIALS AND METHODS}

The present study was a questionnaire survey conducted at Maitri College of Dentistry \& Research Centre, Durg. The study samples of 250 subjects were randomly selected from patients, persons accompanying the patients, and from the residents of Durg. The sample population consists of 142 males and 108 females within age range of 21 to 91 years. A self-designed questionnaire containing nineteen questions was designed on knowledge and awareness for different Prosthodontic treatment modalities and reasons for choosing or refusing treatments were measured. 
The dentist, dental technicians, and assistants were excluded from the study. Sociodemographic details including age, gender, etc. were noted. A total of 250 questionnaire forms were distributed $\&$ collected responses were tabulated.

\section{Statistical Analysis}

Data was statistically analysed using the SPSS 16.0 program. Frequencies were generated and mean calculated with standard deviation using descriptive statistical analysis. Chisquared test was used to identify significance. The probability was assessed using $\mathrm{P}$ value by considering $\mathrm{p}<0.05$ as significant.

\section{Questionnaire}

Survey to analyse the Knowledge of Prosthodontic Rehabilitation.

\section{Q. No. Question}

1) Are you aware that missing teeth have to be replaced? Yes / No

The various types of replacement that they are aware of
a. Complete Denture.
b. Removable Partial Denture.
c. Fixed Partial Denture.
d. Implants.

2) Do you have any missing teeth? Yes / No If Yes: Anterior / Posterior.

3) How long have the teeth been missing? Year...... Month...... Days......

4) Did you get them replaced? Yes / No If yes type of replacement:
a. Complete Denture.
b. Removable Partial Denture.
c. Fixed Partial Denture.
d. Implant supported.

If not replaced then why?
a. Financial constraints.
b. Inadequate knowledge.
c. Not motivated.
d. Rumours.

5) What would you choose between fixed \& removable prostheses?

Fixed/Removable.

6) Where would you like to go for replacement of missing teeth?
a. Dental clinic.
b. General hospital.
c. Dental college.
d. Others (please mention).

7) Are you aware that there is a Dental college where replacement of missing teeth is done in your district? Yes/ No

8) Have you faced any problem during and/or after dental treatment? Yes/ No
9) Do you have any fear related to prosthetic treatment? Yes/ No.
If yes
a. Fear of swallowing.
b. Fear of prosthesis coming out.
c. Fear of discomfort.
d. Fear of gagging.
e. Fear of allergic reaction.

10) Have you experienced failure/repeat of any prosthetic treatment? Yes / No.

11) Will quality of your life improve after prosthetic treatment? Yes/ No.

12) Will your masticatory ability improve after prosthetic treatment? Yes/ No.

13) Why you underwent prosthetic treatment?
a. For aesthetics.
b. For mastication.
c. For speech/phonetics.
d. Others.

14) Are you content with your oral prosthesis? Yes/ No.

15) Do you let your dentist decide with regard to your prosthetic treatment? Yes/ No.

16) If you are not satisfied with the treatment options, do you choose another dentist? Yes/ No.

17) Do you talk to your family about prosthetic treatment options? Yes/ No.

18) Do you consider dental prosthetic treatment is too expensive? Yes/ No.

19) Do you think that prosthesis needs oral hygiene maintenance as natural teeth? Yes/ No.

\section{RESULTS}

The study sample consisted of $56.8 \%$ males $(\mathrm{N}=142)$ and $43.2 \%$ females $(\mathrm{N}=108)$ with a mean age of $39.048 \pm 13.66$ years. Analysis of sociodemographic details shows that there was no statistically significant difference between the gender distribution and age of the sample population $\mathrm{P}=0.94$. Each question was analysed for the frequency, and the relation between the gender difference was tabulated. (Table 1).

\section{Question 1}

Awareness about missing teeth replacement: The results show that $10.0 \%(\mathrm{~N}=25)$ of the study population, including both males and females, has the awareness that they have to replace the missing tooth. There was no statistically significant difference between the genders. (Table 2).

Knowledge about various treatment options: Out of the 250 individuals, $100 \%(\mathrm{~N}-250), 43.77 \%(\mathrm{~N}=109), 80.7 \%$ $(\mathrm{N}=201)$ and $10.84 \%(\mathrm{~N}=27)$ had the knowledge of Complete Denture, Removable Partial Denture, Fixed Partial denture 
and Implants respectively. There were no significant differences noted statistically, $\mathrm{P}>0.05$.

\section{Question 2}

Have any missing teeth: $84 \%(\mathrm{~N}=210)$ individuals that participated in this study had missing teeth. The males showed a higher frequency of missing teeth than females. This result was statistically proven with chi square test, $\mathrm{P}=0.23$ (Table 3). There was no statistical difference between the loss of anterior and posterior teeth.

\section{Question 3}

Duration of tooth loss: The duration of missing teeth among the participants of the survey was $15.12+10.10$ months for males and $10.34+10.22$ months for females. There was no statistical difference between the genders, $\mathrm{P}<0.001 \mathrm{HS}$. (Table 4).

\section{Question 4}

Attitude towards prosthetic rehabilitation: Considering the attitude towards the replacement of the missing teeth with prosthesis $33.3 \%(\mathrm{~N}=210)$ individuals were positive and were planning to replace the missing teeth. But there were no significant differences between the genders even though comparatively more men were willing for replacement. (Table 5).

\section{Question 5}

Type of Replacement perceived: Comparison of the individual's knowledge towards different prosthetic replacement options and their perceived option for replacing the missing tooth were as follows. Most of the people were willing to replace the missing teeth with complete denture i.e., $42.85 \%(\mathrm{~N}=30 / 70)$, compared to $28.57 \%(\mathrm{~N}=20 / 70)$ for fixed partial denture and $21.42 \%(\mathrm{~N}=15 / 70)$ for removable partial denture. The individuals did not prefer to replace their missing teeth with implants, i.e., $7.1 \%(\mathrm{~N}=5 / 70)$. But these results were not significant within groups and between genders. (Table 6).

\section{Question 6}

Reasons for not replacing the missing teeth: The main reason for not undergoing the prosthodontic replacement was financial constraint \& rumours in this study population (28.57, $\mathrm{N}=140$ ), followed by lack of knowledge, regarding the prosthetic replacements $(22.85 \%, \mathrm{~N}=140)$ and lack of motivation by the dentist towards the same $(20.01 \%, \mathrm{~N}=140)$ and these observations were not statistically significant. (Table 7).

\section{Question 7}

Choice of place for replacing missing teeth: $55 \%$ chose to get treated in dental college followed by dental clinic (45\%). $(\mathrm{N}=250)$. (Table 8).

\section{Question 8}

How many patients who underwent dental treatment faced problems? $42.85 \%$ patients faced problem during or after seeking dental treatment (30 out of 70 patients faced problems) while 40 patients out of 70 were satisfied with their dental treatment (57.14\%). (Table 9).

\section{Question 9}

Do you have any fear related to prosthetic treatment? 200 out of 250 patients said yes (80\%). (Table $10 \& 11$ ).

97 patients feared of discomfort followed by patients fearing of prosthesis coming out (68). 54 patients feared of discomfort during swallowing.

\section{Question 10}

Have you experienced failure/repeat of any prosthetic treatment? Out of 70 patients, 19 ( 8 male, 11 female) had experienced failure with earlier treatment $(27.14 \%)$. (Table 12).

\section{Question 11}

Will quality of your life improve after prosthetic treatment? $78.57 \%$ (55 patients out of 70 ) patients had improvement in quality of life after treatment. (Table 13).

\section{Question 12}

Will your masticatory ability improve after prosthetic treatment? 56 (out of 70 ) had their mastication improved after prosthetic treatment (80\%). (Table 14).

\section{Question 13}

Why you underwent prosthetic treatment? The main reason for undergoing the prosthodontic replacement was aesthetics- 33 out of 70 patients, $47.1 \%$; for mastication- 31 patients, $\mathrm{N}=70,44.28 \%$; for speech- 6 patients, $8.5 \%$. (Table 15).

\section{Question 14}

Are you content with your oral prosthesis? 56 patients were satisfied with their oral prosthesis i.e. $80 \%(\mathrm{~N}=70)$. (Table 16).

\section{Question 15}

Do you let your dentist decide with regard to your prosthetic treatment? $88 \%$ patients (220 out of 250 ) let their dentist decide the treatment plan. (Table 17).

\section{Question 16}

If you are not satisfied with the treatment option, do you choose another dentist? 220 out of 250 were willing to change their dentist if not satisfied with the treatment plan (88\%). (Table 18).

\section{Question 17}

Do you talk to your family about prosthetic options? 207 out of 250 discuss about prosthetic treatment options with their family. (Table 19).

\section{Question 18}

Do you consider dental prosthetic treatment is too expensive? 60.8\% (152) patients believed dental prosthetic treatment to be very expensive. (Table 20).

\section{Question 19}

Do you think that prosthesis needs oral hygiene maintenance as natural teeth? $66.4 \%$ (166 patients) believed that prosthesis needs oral hygiene maintenance. (Table 21). 


\begin{tabular}{|c|c|c|}
\hline & $\mathbf{N}$ & $\mathbf{\%}$ \\
\hline Male & 142 & \\
\hline Female & 108 & \\
\hline Total & $\mathbf{2 5 0}$ & $\mathbf{1 0 0}$ \\
\hline \multicolumn{3}{|c|}{ Table 1 } \\
\hline
\end{tabular}

\begin{tabular}{|c|c|c|c|}
\hline $\begin{array}{c}\text { Are you Aware that Missing Teeth } \\
\text { have to be Replaced? }\end{array}$ & Male & Female & $\begin{array}{c}\text { P } \\
\text { value }\end{array}$ \\
\hline Yes & 142 & 108 & \\
\hline No & 0 & 0 & \\
\hline Total & $\mathbf{1 4 2}$ & $\mathbf{1 0 8}$ & \\
\hline \multicolumn{2}{|c|}{ Table 2 } \\
\hline
\end{tabular}

\begin{tabular}{|c|c|c|c|}
\hline Do you have any Missing teeth? & Male & Female & P value \\
\cline { 1 - 3 } Anterior & 31 & 30 & \multirow{2}{*}{0.23} \\
\cline { 1 - 3 } Posterior & 89 & 60 & \\
\hline Total Table 3 & $\mathbf{1 2 0}$ & $\mathbf{9 0}$ & \\
\hline \multicolumn{3}{|c|}{} \\
\hline
\end{tabular}

\begin{tabular}{|c|c|c|}
\hline $\begin{array}{l}\text { How Long have the Teeth been } \\
\text { Missing? }\end{array}$ & Mean \pm SD & $P$ value \\
\hline Male & $15.12 \pm 10.10$ & \multirow{3}{*}{$\begin{array}{c}<0.001 \\
\text { HS }\end{array}$} \\
\hline Female & $10.34 \pm 10.22$ & \\
\hline Total & $13.4 \pm 10.27$ & \\
\hline \multicolumn{3}{|l|}{ Table 4} \\
\hline
\end{tabular}

\begin{tabular}{|c|c|c|c|}
\hline $\begin{array}{c}\text { Did you get them } \\
\text { Replaced? }\end{array}$ & Male & Female & P value \\
\hline Yes & 40 & 30 & \multirow{2}{*}{1.00 NS } \\
\hline No & 80 & 60 & \\
\hline Total & $\mathbf{1 2 0}$ & $\mathbf{9 0}$ & \\
\hline \multicolumn{4}{|c}{ Table 5 } \\
\hline
\end{tabular}

\begin{tabular}{|c|c|c|c|}
\hline $\begin{array}{c}\text { What would you Choose } \\
\text { between fixed \& } \\
\text { Removable Prosthesis? }\end{array}$ & Male & Female & $\begin{array}{c}\text { P } \\
\text { value }\end{array}$ \\
\hline Complete Denture & 17 & 13 & \multirow{2}{*}{0.45 NS } \\
\hline Removable partial Denture & 10 & 10 & \\
\hline Fixed partial Denture & 11 & 4 & \\
\cline { 1 - 3 } Implant supported & 2 & 3 & \\
\cline { 1 - 3 } Total & $\mathbf{4 0}$ & $\mathbf{3 0}$ & \\
\hline \multicolumn{2}{|c}{ Table 6} \\
\end{tabular}

\begin{tabular}{|c|c|c|c|}
\hline $\begin{array}{c}\text { Why did you not get the } \\
\text { Teeth Replaced? }\end{array}$ & Male & Female & $\begin{array}{c}\text { P } \\
\text { value }\end{array}$ \\
\cline { 1 - 3 } Financial constraint & 25 & 15 & \multirow{2}{*}{0.08} \\
\cline { 1 - 3 } Inadequate knowledge & 20 & 12 & \\
\hline Not motivated & 10 & 18 & \\
\hline Rumours & 25 & 15 & \\
\hline Total & $\mathbf{2 5}$ & $\mathbf{1 5}$ & \\
\cline { 1 - 1 } & \\
\hline
\end{tabular}

\begin{tabular}{|c|c|c|c|}
\hline $\begin{array}{c}\text { Where would you like to go } \\
\text { for Replacement of Missing } \\
\text { Teeth? }\end{array}$ & Male & Female & $\begin{array}{c}\text { P } \\
\text { value }\end{array}$ \\
\cline { 1 - 3 } Dental clinic & 72 & 40 & \multirow{2}{*}{0.20} \\
\hline General Hospital & 0 & 0 & \\
\hline Dental college & 70 & 68 & \\
\hline Others & 0 & 0 & \\
\hline Total Table 8 & $\mathbf{1 4 2}$ & $\mathbf{1 0 8}$ & \\
\hline \multicolumn{2}{|c|}{} \\
\cline { 1 - 3 }
\end{tabular}

\begin{tabular}{|c|c|c|c|}
\hline $\begin{array}{c}\text { How many Patients who } \\
\text { Underwent Dental } \\
\begin{array}{c}\text { Treatment Faced } \\
\text { Problems? }\end{array}\end{array}$ & Male & Female & $\begin{array}{c}\text { P } \\
\text { value }\end{array}$ \\
\hline Yes & 14 & 16 & \multirow{2}{*}{0.12 NS } \\
\hline No & 26 & 14 & \\
\hline Total & $\mathbf{4 0}$ & $\mathbf{3 0}$ & \\
\hline \multicolumn{2}{|c}{ Table $\mathbf{9}$} \\
\end{tabular}

\begin{tabular}{|c|c|c|c|}
\hline $\begin{array}{c}\text { Do you have any fear } \\
\text { Related to Prosthetic } \\
\text { Treatment? }\end{array}$ & Male & Female & $\begin{array}{c}\text { P } \\
\text { value }\end{array}$ \\
\hline Yes & 115 & 85 & \multirow{2}{*}{0.65 NS } \\
\hline No & 27 & 23 & \\
\hline Total & $\mathbf{1 4 2}$ & $\mathbf{1 0 8}$ & \\
\hline \multicolumn{3}{|c|}{ Table 10 } \\
\hline
\end{tabular}

\begin{tabular}{|c|c|c|c|}
\hline $\begin{array}{c}\text { Reason for Fear of Prosthetic } \\
\text { Treatment }\end{array}$ & Male & Female & $\begin{array}{c}P \\
\text { value }\end{array}$ \\
\hline Fear of swallowing & 35 & 19 & \multirow{5}{*}{0.42} \\
\hline Fear of prosthesis coming out & 34 & 34 & \\
\hline Fear of discomfort & 56 & 41 & \\
\hline Fear of gagging & 17 & 14 & \\
\hline Fear of allergic reaction & 0 & 0 & \\
\hline Total & 142 & 108 & \\
\hline \multicolumn{4}{|c|}{ Table 11} \\
\hline
\end{tabular}

\begin{tabular}{|c|c|c|c|}
\hline $\begin{array}{c}\text { Have you } \\
\text { Experienced } \\
\begin{array}{c}\text { Failure/Repeat of } \\
\text { any Prosthetic } \\
\text { Treatment? }\end{array}\end{array}$ & Male & Female & \multirow{2}{*}{ P value } \\
\hline Yes & 8 & 11 & \\
\hline No & 22 & 19 & \multirow{2}{*}{0.40} \\
\hline Total & $\mathbf{4 0}$ & $\mathbf{3 0}$ & \\
\hline \multicolumn{3}{|c|}{ Table 12 } \\
\hline
\end{tabular}

\begin{tabular}{|c|c|c|c|}
\hline $\begin{array}{c}\text { Will quality of your life } \\
\text { Improve after Prosthetic } \\
\text { Treatment? }\end{array}$ & Male & Female & $\begin{array}{c}\mathbf{P} \\
\text { value }\end{array}$ \\
\hline Yes & 31 & 24 & 0 \\
\hline No & 9 & 6 & 0.80 \\
\hline Total & $\mathbf{4 0}$ & $\mathbf{3 0}$ & \\
\hline \multicolumn{3}{|c}{ Table 13 } \\
\hline
\end{tabular}

\begin{tabular}{|c|c|c|c|}
\hline $\begin{array}{c}\text { Will your Masticatory Ability } \\
\text { Improve after Prosthetic } \\
\text { Treatment? }\end{array}$ & Male & Female & $\begin{array}{c}\text { P } \\
\text { value }\end{array}$ \\
\hline Yes & 34 & 22 & \multirow{2}{*}{0.23} \\
\hline No & 6 & 8 & \\
\hline Total & $\mathbf{4 0}$ & $\mathbf{3 0}$ & \\
\hline \multicolumn{2}{|c}{ Table 14 }
\end{tabular}

\begin{tabular}{|c|c|c|c|}
\hline $\begin{array}{c}\text { Why you Underwent } \\
\text { Prosthetic } \\
\text { Treatment? }\end{array}$ & Male & Female & $\begin{array}{c}\text { P } \\
\text { value }\end{array}$ \\
\hline For aesthetics & 18 & 15 & \multirow{2}{*}{0.137} \\
\hline For mastication & 21 & 10 & 5 \\
\hline For speech & 01 & 0 & \\
\hline Others & 0 & $\mathbf{3 0}$ & \\
\hline Total & $\mathbf{4 0}$ & Table 15 \\
\hline \multicolumn{4}{|c|}{}
\end{tabular}




\begin{tabular}{|c|c|c|c|}
\hline $\begin{array}{c}\text { Are you Content } \\
\text { with your Oral } \\
\text { Prosthesis? }\end{array}$ & Male & Female & \multirow{2}{*}{$\begin{array}{c}\text { P } \\
\text { value }\end{array}$} \\
\hline Yes & 33 & 23 & \multirow{2}{*}{0.54 NS } \\
\hline No & 07 & 07 & \\
\hline Total & $\mathbf{4 0}$ & $\mathbf{3 0}$ & \\
\hline \multicolumn{3}{|c|}{ Table 16 } \\
\hline
\end{tabular}

\begin{tabular}{|c|c|c|c|}
\hline $\begin{array}{c}\text { Do you let your Dentist } \\
\text { decide with regard to } \\
\text { your Prosthetic } \\
\text { Treatment? }\end{array}$ & Male & Female & $\begin{array}{c}\text { P } \\
\text { value }\end{array}$ \\
\hline Yes & 119 & 101 & \multirow{2}{*}{0.019 HS } \\
\hline No & 23 & 7 & \\
\hline Total & 142 & 108 & \\
\hline \multicolumn{3}{|c|}{ Table 17 } \\
\hline
\end{tabular}

\begin{tabular}{|c|c|c|c|}
\hline $\begin{array}{c}\text { If you are not Satisfied } \\
\text { with the Treatment } \\
\text { Option, do you choose } \\
\text { another Dentist? }\end{array}$ & Male & Female & $\begin{array}{c}\text { P } \\
\text { value }\end{array}$ \\
\hline Yes & 130 & 90 & 0.047 \\
\hline No & 12 & 18 & SIGNI \\
\hline Total & $\mathbf{1 4 2}$ & $\mathbf{1 0 8}$ & \\
\hline \multicolumn{3}{|c|}{ Table 18 } \\
\hline
\end{tabular}

\begin{tabular}{|c|c|c|c|}
\hline $\begin{array}{c}\text { Do you talk to your } \\
\text { Family about } \\
\text { Prosthetic Options? }\end{array}$ & Male & Female & $\begin{array}{c}\text { P } \\
\text { value }\end{array}$ \\
\hline Yes & 101 & 106 & $<0.00001$ \\
\hline No & 41 & 2 & \\
\hline Total & $\mathbf{1 4 2}$ & $\mathbf{1 0 8}$ & \\
\hline \multicolumn{3}{|c|}{ Table 19 } \\
\hline
\end{tabular}

\begin{tabular}{|c|c|c|c|}
\hline $\begin{array}{c}\text { Do you consider Dental } \\
\text { Prosthetic Treatment is } \\
\text { too Expensive? }\end{array}$ & Male & Female & $\begin{array}{c}\text { P } \\
\text { value }\end{array}$ \\
\hline Yes & 80 & 72 & \multirow{2}{*}{0.097} \\
\hline No & 62 & 36 & \\
\hline Total & 142 & 108 & \\
\hline \multicolumn{4}{|c|}{ Table 20 } \\
\hline
\end{tabular}

\begin{tabular}{|c|c|c|c|}
\hline $\begin{array}{c}\text { Do you think that } \\
\text { Prosthesis needs oral } \\
\text { Hygiene Maintenance } \\
\text { as Natural Teeth? }\end{array}$ & Male & Female & $\begin{array}{c}\text { P } \\
\text { value }\end{array}$ \\
\hline Yes & 90 & 76 & \multirow{2}{*}{0.24} \\
\hline No & 52 & 32 & \\
\hline Total & $\mathbf{1 4 2}$ & $\mathbf{1 0 8}$ & \\
\hline \multicolumn{3}{|c|}{ Table 21 } \\
\hline
\end{tabular}

\section{DISCUSSION}

In India, epidemiological data on patients' attitude towards tooth replacement are scarce. Therefore, an attempt was made to find out the attitude towards replacement of teeth among patients reporting to the Maitri College of Dentistry \& Research Centre, Durg. Two hundred fifty patients reported for the study, male patients being more in number.

Most of the patients belonged to the forty to fifty-five years age. Older people make extensive use of medical facilities, but they seem to underuse dental facilities. Lack of information, and misconceptions about the value of dental visits have been mentioned as contributing to this apparent disinterest in dental care among geriatric patients. ${ }^{5}$

Individuals with greater financial resources have better access to dental care. Those who have attained higher levels of education are more apt to have greater financial opportunity and to place a higher priority on dental health. Lack of education about the importance of oral health, the need for preventive services, and the consequences of neglect appear to constitute a significant barrier to dental health care. ${ }^{6}$

Most patients reported that they had reserved money for health care, which may have been for general health rather than oral health because in India dental health insurance is not very common. In India, overall health insurance coverage is low; less than 10 percent of the population is estimated to have access to health insurance. For the most part, the health care demands of the rural poor and informal workers have been largely unmet. However, several initiatives and experiments have been tried. The Rashtrapati Swasthya Bima Yojna \& The Mukhyamantri Swasthya Bima Yojna of Chhattisgarh Government provide medical \& dental facilities by providing financial insurance to the poor. Since the patients in our study had reported on their own to the institute for replacement of teeth, it was not surprising to find that all the subjects expressed that missing teeth had to be replaced.

Most patients in our study gave financial constraints \& rumours for not replacing teeth. Cost was the main barrier for obtaining dentures and is in agreement with the findings of Macek et al. ${ }^{7}$

Osterberg et $\mathrm{al}^{8}$ reported that aesthetics rather than functional factors determine a young individual's subjective need for the replacement of missing teeth while old age patients crave for functional need of the prosthesis (mastication). The demand for replacement of missing teeth is strongly related to the position of the missing teeth. Replacement of missing posterior teeth, and cosmetic dental treatment in general, depends on the perception of the patient. Even in countries with highly developed dental care systems, open spaces in the premolar and molar regions are well accepted by people of all ages. The prospect of a good aesthetic result frequently motivates the patient to wear a new denture, and aesthetics can be more important than function for many individuals. ${ }^{9}$ In our study, patients who had lost teeth only in the anterior segment needed tooth replacement for aesthetics; those who had lost teeth only in the posterior segment needed tooth replacement for mastication; and patients with teeth missing in both the anterior and posterior segment needed tooth replacement for mastication. These findings could be explained by the fact that most people in India are aware of only the mastication function served by the teeth. They are less aware of the aesthetic and phonetic functions of teeth. According to Leake et $\mathrm{al}^{10}$ the subjective need for prosthetic replacement of teeth, particularly posterior teeth, is often low because such replacements seldom improve the individual's social status Moreover, as tooth loss usually occurs gradually over a period of time, it allows the individual to adapt to the situation with no apparent complaints. Therefore, many older individuals may not perceive a need for dentures in spite of 
losing significant numbers of teeth because they have adapted to their missing teeth over time. ${ }^{11}$

When a question regarding equivalence of artificial teeth to natural teeth was asked, it indirectly represented the expectation of the patient. Expectations represent attitudes that are complex and often difficult to change. In our study, a higher number of patients said that artificial teeth were equivalent to natural teeth. They might have perceived this because of the matching of the colour and anatomy of the artificial teeth to the natural teeth, the resiliency of the acrylic tooth material, or the care taken by the operator during tooth selection.

Most patients knew that artificial teeth create no problems. Patient education before, during, and after prosthodontic treatment may have prevented the expected problems with the artificial teeth or prosthesis. Patients' perceptions regarding replacement of teeth may have been better appreciated if differences in attitude among denturewearers and non-denture-wearers had been analysed in our study.

The knowledge and attitude of patients towards the replacement of teeth would prepare a prosthodontist to provide a satisfying prosthesis. Knowledge of patient expectations can help in planning a prosthesis in harmony with the hard and soft oral tissues and in harmony with the patient's expectations as well.12 Future studies should determine how the dental profession might help an increased demand for dental services among people who have limited financial resources \& would provide important insights into the various types of assistance and insurance programs that might be designed and implemented to benefit older adults.

\section{CONCLUSION}

The present results may serve as a baseline for the future evaluation of attitudes towards replacement of teeth. The findings indicate that awareness needs to be created regarding the other functions of teeth like aesthetics and phonetics because many subjects in this study were only aware of the masticatory function performed by teeth, especially among individuals in the lower socioeconomic group. ${ }^{13}$ Attitudes of patients towards replacement of teeth should be assessed to educate the patient accordingly and improve patient compliance with acceptance of prostheses.

The acceptance of dental implants and other advanced treatment modalities other than the conventional complete denture and removable partial denture options in the elderly population might be increased by providing further knowledge and awareness and promoting oral health in general.

\section{REFERENCES}

[1] Levinson NA. Psychologic facets of esthetic dental health care: a developmental perspective. J Prosthet Dent 1990;64(4):486-91.

[2] Roessler DM. Complete denture success for patients and dentists. Int Dent J 2003;53(5):340-5.

[3] Omar R, Tashkandi E, Abduljabbar T, et al. Sentiments expressed in relation to tooth loss: a qualitative study among edentulous Saudis. Int J Prosthodont 2003;16(5):515-20.

[4] Fiske J, Davis DM, Frances C, et al. The emotional effects of tooth loss in edentulous people. Br Dent J 1998;184(2):90-3.

[5] Maupome G, MacEntee MI. Prosthodontic profiles relating to economic status, social network, and social support in an elderly population living independently in Canada. J Prosthet Dent 1998;80(5):598-604.

[6] Marcus PA, Joshi A, Jones JA, et al. Complete edentulism and denture use for elders in New England. J Prosthet Dent 1996;76(3):260-6.

[7] Macek MD, Cohen LA, Reid BC, et al. Dental visits among older U.S. adults, 1999: the roles of dentition status and cost. J Am Dent Assoc 2004;135(8):115462.

[8] Osterberg T, Hedegard B, Sater G. Variation in dental health in 70-year-old men and women in Goteborg, Sweden: a cross-sectional epidemiological study including longitudinal and cohort effects. Swed Dent J 1984;8(1):29-48.

[9] Mazurat NM, Mazurat RD. Discuss before fabricating: communicating the realities of partial denture therapy. Part I: patient expectations. J Can Dent Assoc 2003;69(2):90-4.

[10] Leake JL, Hawkins R, Locker D. Social and functional: impact of reduced posterior dental units in older adults. J Oral Rehabil 1994;21(1):1-10.

[11] Pallegedara C, Ekanayake L. Tooth loss, the wearing of dentures, and associated factors in Sri Lankan older individuals. Gerodontology 2005;22(4):193-9.

[12] Conny DJ, Tedesco LA, Brewer JD, et al. Changes of attitude in fixed prosthodontic patients. J Prosthet Dent 1985;53(4):451-4.

[13] Khan SA, Dawani N, Bilal S. Perceptions and myths regarding oral health care amongst strata of low socio economic community in Karachi, Pakistan. J Pakistan Med Ass 2012;62(11):1198-203. 